\title{
Physico-chemical Characterization of the Leachate from Fermentation Composts Treated with Lime and Soda: Case of the Composting Platform in Aného, Togo
}

\author{
Edem K. Kolédzi ${ }^{1^{*}}$, Nitale M’Balikine Krou², Kwamivi N. Ségbéaya ${ }^{2}$ \\ and E. Aziablé ${ }^{1}$ \\ ${ }^{1}$ Laboratory of Management, Treatment and Valorization of Waste (GTVD), Faculty of Science, \\ University of Lomé; BP 1515 Lomé, Togo. \\ ${ }^{2}$ Laboratory for Sanitation, Water Sciences and Environment (LASEE), Faculty of Science and \\ Technology, University of Kara; B. P404 Kara-Togo.
}

Authors' contributions

This work was carried out in collaboration among all authors. Author EKK designed the study, performed the statistical analysis, wrote the protocol and wrote the first draft of the manuscript. Author NM'BK and E A managed the analyses of the study. Author KNS managed the literature searches. All authors read and approved the final manuscript.

Article Information

DOI: 10.9734/ARRB/2021/v36i230347 Editor(s):

(1) Dr. Md. Torequl Islam, Federal University of Piaui, Brazil. Reviewers:

(1) Latifah binti Omar, University Putra Malaysia, Malaysia. (2) Magdalena Myszura, University of Life Sciences in Lublin, Poland. (3) Nurhan Varol, Olive Research Institute, Turkey. Complete Peer review History: http://www.sdiarticle4.com/review-history/66857

Original Research Article

Received 15 January 2021

Accepted 17 March 2021

Published 30 March 2021

\begin{abstract}
This study aims to determine the parameters measuring the reduction rate of the organic matter during fermentation and its bio-availability after maturation of the compost made using fermentable fractions of household waste. Thus, a physico-chemical characterization of the raw leachate and the leachate treated with lime and caustic soda was carried out. The results showed that, the contents of the other parameters measured are higher for the raw leachate compared to those obtained for the treated leachate. Organic and inorganic pollution is reflected by high Chemical Oxygen Demand (COD), absorbance at $254 \mathrm{~nm}$, turbidity and suspended matter. The COD values in the raw leachate
\end{abstract}


vary between 13000 and $19150 \mathrm{mg} / \mathrm{O}_{2} / \mathrm{L}$; those of the absorbance at $254 \mathrm{~nm}$ between 30.5 and 34.15 OD; those of turbidity between 156 and 255 NTU (Nephelometric Turbidity Unit) and those of suspended matter between 48 and $1600 \mathrm{mg} / \mathrm{L}$. In the treated leachate, the COD values oscillate between 4489 and $8743 \mathrm{mg} / \mathrm{O}_{2} / \mathrm{L}$; those of the absorbance at $254 \mathrm{~nm}$ between 6.69 and $31.1 \mathrm{OD}$; those of turbidity between 57.8 and 122 NTU and those of suspended matter between 70 and 92 $\mathrm{mg}$. These results reflect a good reduction after treatment with lime and soda.

Keywords: Abatement; absorbance; leachate; turbidity; compost.

\section{INTRODUCTION}

Composting is one of the most popular urban waste management solutions in the world. The aim is to face not only the problems of unsanitary conditions in cities, in particular cities in developing countries (DCs), but also to deal with the thorny problems of environmental pollution. One of the major concerns associated with this management method is the production of large quantities of liquid effluents which are very rich in different substances, namely organic and mineral matter called leachate or juice. Indeed, this leachate comes from the percolation of rainwater through the deposits as well as the water contained in the waste and that of its degradation $[1,2]$. Once deposited, this waste undergoes degradation phenomena or processes due to fairly complex physico-chemical and biological reactions. The water infiltrates and produces leachate rich in organic substances (biodegradable, but also refractory to biodegradation) and minerals which are at the origin of organic and inorganic pollution, linked to the natural biodegradation of the contained waste. These leachates would be a potential source of contamination of the surrounding environments if they are not collected and treated $[1,2]$

Thus, in Morocco, the study of the physicochemical quality of groundwater near the Casablanca landfill revealed high levels not only of major elements but also of metallic elements from the leachate from this landfill [3]. Studies carried out by [4] on the leachate from the Technical Landfill Center (CET) in the city of Oujda (Morocco) showed high levels of biodegradable organic matter, heavy metals, mineral matter and suspension [5], in Algeria, in their study on the Tiaret landfill, showed that the leachate contains many organic and metallic contaminants above the accepted standards. [6] in their work on the El Kerma landfill showed similar results [7]. In Côte d'Ivoire in 2000, carried out specific studies on the evaluation of the physico-chemical parameters of surface water downstream of the Akouédo landfill in order to assess their degree of contamination by leachate. On the other hand, [8] using a mathematical model, followed the evolution of leachate from the Akouédo landfill and assessed their impact on the quality of groundwater. The studies carried out by Adjiri in 2010 made it possible to characterize the chemical and microbiological pollution of the Akouédo environment in order to quantify the health risks associated with this pollution.

This study aims to determine the parameters measuring the reduction rate which provides information on the evolution of organic matter during fermentation and its bio-availability after maturation of the compost produced with fermentable fractions of solid waste at the composting platform in the city of Aného, Togo.

\section{MATERIALS AND METHODS}

\subsection{Study Zone}

The study area is in the municipality of Lakes 1 (Fig. 1) located in the prefecture of lakes with the capital of Aného which is located in the maritime region. The Municipality of Lakes 1 is bounded to the North and North-East by the Municipalities of Lakes 4 (Anfoin, Fiata, Ganavé) and Lakes 2 (Aklakou, Agouègan), to the South by the Atlantic Ocean, to the East by the Republic of Benin and to the West by the Municipality of Lakes 3 (Agbodrafo).

The Commune is characterized by the tropical climate of the Guinean type which manifests itself by two rainy seasons (March-July and September-October) and two dry seasons (August-September and October-February). These different seasons are increasingly disrupted by climatic anomalies. The rains become irregular, sometimes abundant (which causes flooding in places), sometimes rare. The average rainfall varies between 900 and 1500 $\mathrm{mm}$ per year, and temperatures vary between $25^{\circ} \mathrm{C}$ and $37^{\circ} \mathrm{C}$. At times, a higher or lower temperature trend is recorded. 
The vegetation to the south of the Commune is made up of aquatic trees (planted mangroves) and coconut palms, many of which have been destroyed by Kangnikopé disease or washed away by the ever-advancing sea. There are sandy soils favorable to the planting of coconut palms and market gardening. The forest tends to disappear due to human actions.

In the north of the Commune, the vegetation is made up of trees of different forest and aquatic species, all of which form the savannah, with a good number of forests being destroyed for the benefit of agriculture. Even the sacred forests have suffered heavy losses today. These are essentially the two sacred forests Avégbatso in Glidji Kpodji and Ananavé in Glidji, which host worship and ritual ceremonies. The Municipality opens onto a sea plan (about $12 \mathrm{~km}$ ) and has a network of rivers: the Gbaga channel and Lake Zowla.

\subsection{Compost Raw Materials}

The raw materials used for composting in this study are the fermentable fractions of household waste. These composts were produced on the composting platform of Aného managed by the municipality unlike that of Lomé, managed by the NGO ENPRO (Ecosystème Naturel Propre). Unlike ENPRO, failure to control the amount of water to be supplied to the piles (windrows) produces enormous leachate especially during pile formation and during fermentation. This therefore creates an environmental nuisance. This waste is deposited alternately in a series of layers and to allow aeration of the mixture an inversion is carried out every week.

\subsection{Preparation of Samples}

Four piles were prepared and watered in the same manner as all the others on the platform (Fig. 2). Small basins are created to collect the leachate. The leachate samples $\left(E_{1}, E_{2}, E_{3}, E_{4}\right)$ were taken at the end of the fermentation and sent to the Laboratory.

\subsection{Analyzes Carried Out on the Leachate from the Compost}

The study of the characterization of the leachate resulting from the composting of fermentable fractions of household waste is a key factor which indicates the predisposition of waste deposits to biodegradation. Samples were taken during fermentation and maturation. The quantity of uncollected leachate on the composting platform is estimated at 5500 liters per month. The leachates from the composts are prepared in a solid / liquid ratio equal to $1 / 2$, i.e. $25 \mathrm{~g}$ of compost sieved at $2 \mathrm{~mm}$ in $50 \mathrm{~mL}$ of distilled water. In the absence of reference parameters, the parameters deemed to be the most relevant are only taken into account in this study. Parameters such as $\mathrm{pH}$, conductivity, volatile fatty acids (VFA), UV-254 absorbance, COD, turbidity, suspended matter (SS) are taken into consideration to characterize the different leachate. These various parameters are measured on the raw leachate and on the leachate treated (with lime and soda) according to the AFNOR standards in force.

\subsection{Statistical Analysis}

The data collected were subjected to a two-tailed equality of expectations test. The means were compared using the Student-Newman-Keuls test at the $5 \%$ threshold. Values followed by the same letter are not significantly different (Duncan, $p \leq 0.05$ ).

\section{RESULTS AND DISCUSSION}

Characterization of the raw leachate and the leachate after settling and filtration.

The characterization of the leachate resulting from the open-air composting of agricultural waste mixed with household waste produced on the Aného composting platform focused on various parameters. To determine these parameters, several analyzes are carried out either on the raw leachate, or on the leachate after settling and filtration, or on the raw leachate treated with lime or soda and either on the treated and filtered raw leachate.

The measurement of suspended matter (SS) makes it possible to evaluate the particle transfer between the solid and liquid phases during the leaching test and to deduce the degree of mechanical degradation of the materials put into composting. Estimating the organic load of leachate is a key indicator of the state of degradation of composted waste. This evaluation of the organic load is made by combining several parameters, namely the Chemical Oxygen Demand (COD), the UV absorbance concentration at $254 \mathrm{~nm}$, the turbidity and the content of Volatile Fatty Acids (VFA).

Thus, in Table 1, the results of analyzes of the various parameters on the characterization of the 
raw leachate and the leachate after settling and filtration are presented.

Analysis of the results of the $\mathrm{pH}$ measurement shows that the $\mathrm{pH}$ of the raw leachate varies between 7.54 and 7.76; on the other hand, the $\mathrm{pH}$ of the leachate after decantation and filtration varies between 6.07 and 7.94. The raw leachate has a slightly alkaline $\mathrm{pH}$, which could be due to the presence of ash in the composted waste. This presence of ash is probably due to the fact that in Aného, most households use wood or charcoal for cooking. This result corroborates with those of the literature $[9,10]$ Moreover, these high $\mathrm{pH}$ values obtained show that the leachate is no longer young [11]. The difference between the two measures is not significant $(p \leq 0.05)$.

The determination of the ionic conductivity provides information on the quantity of charged species present in the various leachate. This is a key parameter for estimating the mineral load. The conductivity is higher in the raw leachate compared to that of the leachate after settling and filtration.
The VFA concentration of the raw leachate is $3.36 \mathrm{~g} / \mathrm{L}$ and that of the leachate after settling and filtration is $2.04 \mathrm{~g} / \mathrm{L}$. These low values are indicative of low chemical stability and therefore of a high content of easily biodegradable organic matter [12]. The VFA contents greater than $10 \mathrm{~g} /$ $L$ are a sign of low degradation of organic matter [13].

The COD contents of the raw leachate are very high compared to those of the leachate after decantation and filtration. This difference in values is significant $(p \geq 0.05)$ (Table 3 ). These high COD contents are linked to the high rate of Total Organic Carbon in the basic waste, thus indicating a high organic load. For a leachate of organic matter from a stable waste compost, the COD must be less than or equal to $1220 \mathrm{mgO}_{2} / \mathrm{L}$ $[14,15]$ The COD contents of the raw leachate are greater than $1220 \mathrm{mgO}_{2} / \mathrm{L}$ and those of the leachate after settling and filtration are lower than $1220 \mathrm{mgO}_{2} / \mathrm{L}$. These results indicate stability of the waste after settling and filtration and therefore show the positive effect of settling and filtration.

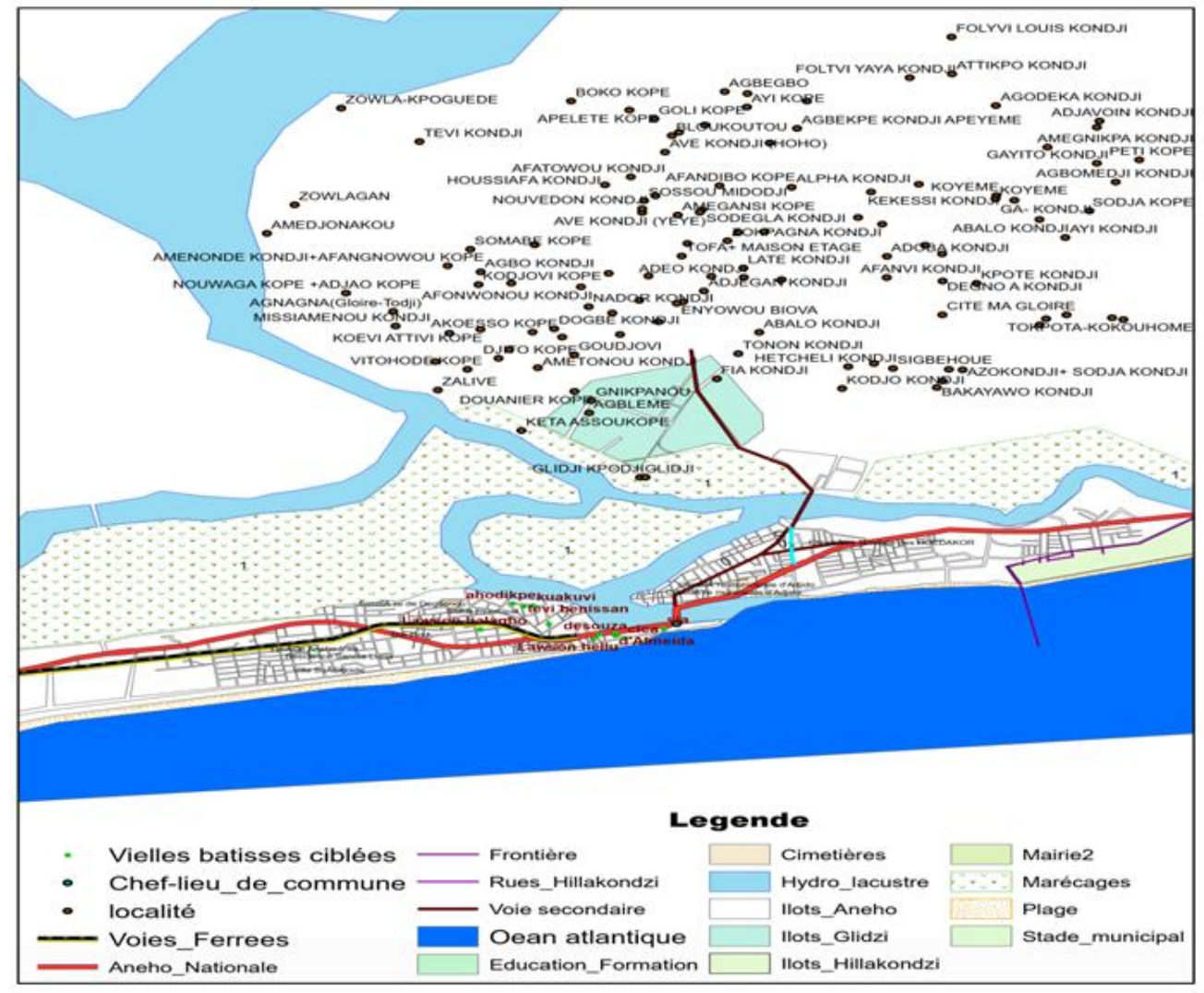

Fig. 1. Map of the municipality of lakes 1 


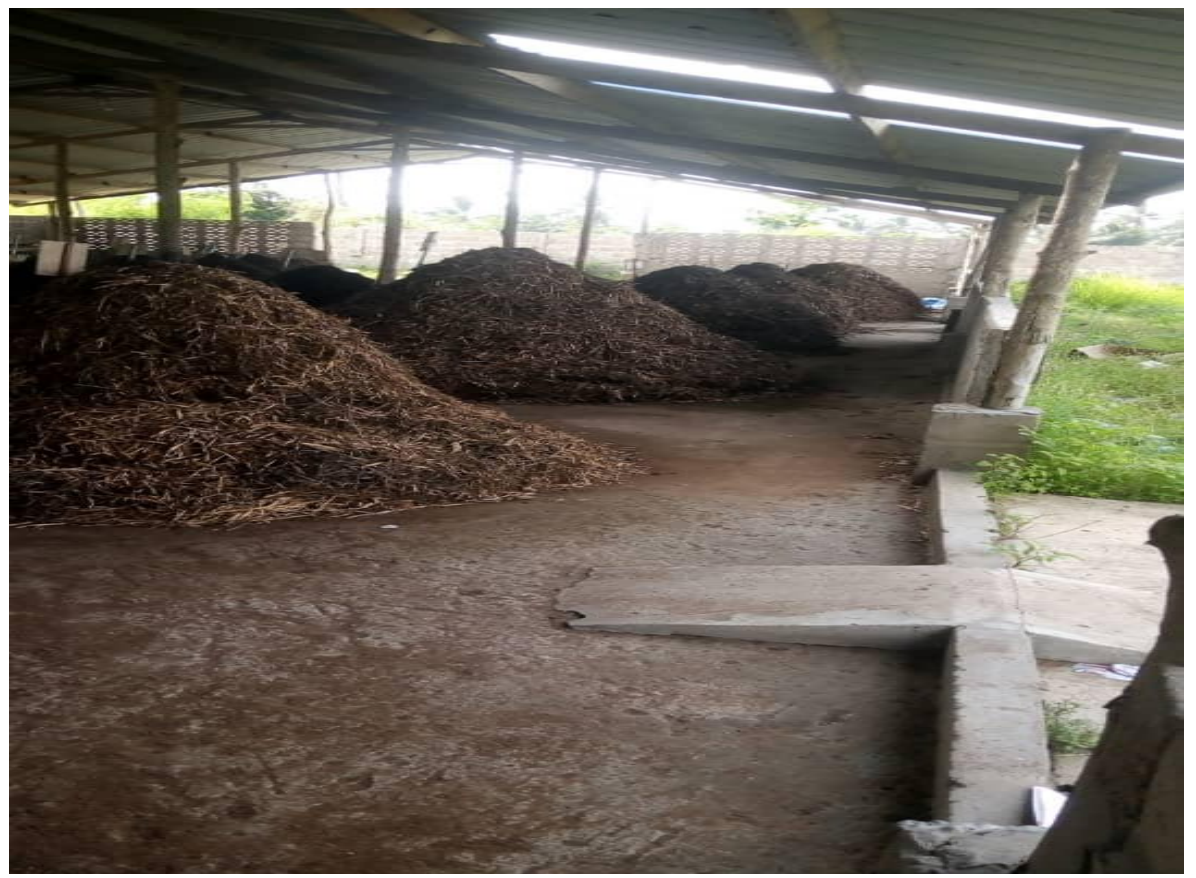

Fig. 2. Pile of composts on the Aného composting platform

The UV absorbance measurement at $254 \mathrm{~nm}$ of the raw leachate is very high compared to that of the leachate after settling and filtration. This measure of absorbance shows significant differences ( $p \geq 0.05$ ) (Table 3 ) between the raw leachate and the leachate after settling and filtration. This difference could be due to the retention of organic matter after passing through the permeate. These high absorbance values show that the raw leachate is very rich in organic matter.

The turbidity and suspended matter measured in the raw leachate are much higher than those measured in the leachate after settling and filtration. The difference between the two measurements is very significant (Table 3$)(p$ $\geq 0.05$ ). These high values (of turbidity and suspended matter) are attributable to organic and inorganic materials. These results are also linked to the low concentration of dissolved oxygen [16].

\section{Characterization of raw leachate treated with lime and with soda}

Table 3 shows the results of parameter measurements on the leachate treated with lime.

Analysis of the results of the $\mathrm{pH}$ and absorbance measurement shows that with lime treatment, the
$\mathrm{pH}$ and absorbance have the same value for the raw leachate as that obtained after filtration. Whatever the leachate, the $\mathrm{pH}$ is alkaline but this value is higher than that obtained for the leachate that has not undergone any treatment. The initial $\mathrm{pH}$ is acidic because this leachate corresponds to the fermentation phase of the garbage which is generally acidic during composting. On the other hand, the absorbance values decreased compared to the leachate without treatment. This result indicates that the lime has absorbed part of the organic matter. For leachate treated with soda, there is an increase between the raw leachate and that which has been filtered. This increase is due to the alkaline nature of soda.

The COD contents of the raw leachate treated with lime are very high compared to those of the leachate after settling and filtration. This difference in values is significant $(p \geq 0.05)$ (Table 3). However, these contents are lower than those of the untreated raw leachate. Which indicates lime will absorb chemically oxidizable organic material. The COD increased after treatment with soda compared to the leachate treated with lime; which indicates a low absorption capacity of organic matter of soda compared to that of lime. 
Table 1. Characteristics of the methods and apparatus used for the physico-chemical analyzes of leaching juices

\begin{tabular}{|c|c|c|c|c|c|}
\hline Parameters & Unit & Cutoff threshold & Reference and standards & Methods and device & Accuracy and limit detection \\
\hline $\mathrm{pH}$ & Unit pH & Gross Centrifugation & NF T90-008 & $\begin{array}{l}\text { pH meter: Eutech Instrument } \\
\text { Model : CyberScan pH } 510 \\
\text { Electrode: } \mathrm{Ag} / \mathrm{AgCl} \text { combined glass }\end{array}$ & \pm 0.1 unit $\mathrm{pH}$ \\
\hline Conductivity (X) & $\mathrm{ms} / \mathrm{cm}$ & Gross Centrifugation & $\begin{array}{l}\text { NF EN } 27888 \\
\text { T90-031 }\end{array}$ & $\begin{array}{l}\text { Brand : WTW } \\
\text { Model : LF } 538 \\
\text { Measuring cell: Tetracon } 325\end{array}$ & $\begin{array}{l}10 \mathrm{C}<\mathrm{T}^{\circ} \mathrm{C}<+55^{\circ} \mathrm{C} \\
\text { erreur max }=0.5 \%\end{array}$ \\
\hline Volatile fatty acid & $\mathrm{gCH}_{3} \mathrm{COOH} / \mathrm{L}$ & $0.45 \mu \mathrm{m}$ & NF T90-105 & Potentiometric dosage & - \\
\hline $\begin{array}{l}\text { Chemical oxygen } \\
\text { demand (COD) }\end{array}$ & $\mathrm{mgO}_{2} / \mathrm{L}$ & $0.45 \mu \mathrm{m}$ & $\begin{array}{l}\text { T90-101 } \\
\text { ISO-15705 }\end{array}$ & $\begin{array}{l}\text { Technique : Rapid analysis kit } \\
\text { Technique: UV spectrophotometer - visible }\end{array}$ & $\begin{array}{l}150-1000 \mathrm{mgO}_{2} / \mathrm{L} \\
\pm 6 \mathrm{mg} \mathrm{O}_{2} / \mathrm{L}\end{array}$ \\
\hline Absorbance UV-254nm & - & $0.45 \mu \mathrm{m}$ & - & $\begin{array}{l}\text { Technique : UV spectrophotometer - visible } \\
\text { Brand : Shimatzu UV } 1700 \text { Pharmas Pec } \\
\text { double beam - quartz tank } 1 \mathrm{~cm}\end{array}$ & \pm 0.005 unit $\mathrm{DO}$ \\
\hline Turbidity & NTU & - & - & & - \\
\hline MES & $\mathrm{mg} / \mathrm{L}$ & $\begin{array}{l}1.2 \mu \mathrm{m} \text { glass fiber filters } \\
\text { (Whatman brand) }\end{array}$ & NF T90-105 & Drying at $105^{\circ} \mathrm{C}$ to constant mass & - \\
\hline
\end{tabular}

Table 2. Characterization of the raw leachate and the leachate after settling and filtration

\begin{tabular}{|c|c|c|c|c|c|c|c|c|c|c|c|c|c|c|}
\hline \multirow[b]{2}{*}{ VFA } & \multicolumn{5}{|c|}{ Raw compost leachate parameters } & & \multirow{2}{*}{$\begin{array}{l}\text { MFT } \\
F=0.2 \mathrm{~mm}\end{array}$} & \multicolumn{7}{|c|}{ Compost leachate parameters after settling } \\
\hline & $\mathrm{pH}$ & COD & $\begin{array}{l}\text { Abs UV } \\
254\end{array}$ & Turbidity & MES & Conductivity & & VFA & $\mathrm{pH}$ & DCO & $\begin{array}{l}\text { Abs UV } \\
254\end{array}$ & Turbidity & MES & Conductivity \\
\hline $\mathrm{gCH}_{3} \mathrm{COOH} / \mathrm{L}$ & & $\mathrm{mgO}_{2} / \mathrm{L}$ & DO & NTU & $\mathrm{mg} / \mathrm{L}$ & $\mathrm{mS} / \mathrm{cm}$ & PTM=1-2 bar & $\mathrm{gCH}_{3} \mathrm{COOH} / \mathrm{L}$ & & $\mathrm{mgO}_{2} / \mathrm{L}$ & DO & NTU & $\mathrm{mg} / \mathrm{L}$ & $\mathrm{mS} / \mathrm{cm}$ \\
\hline & 7.76 & 17068 & 30.5 & 156 & 1600 & 11.49 & $\mathrm{Qr}=2 \mathrm{~m}^{3} / \mathrm{H}$ & & 7.42 & 11680 & 24 & 3.26 & 160 & 11.05 \\
\hline & 7.54 & 13000 & 34.15 & 250 & 350 & 10.05 & & & 7.94 & 10512 & 20 & 17.6 & 28 & 10.59 \\
\hline & 7.6 & & 31.5 & 255 & 379 & & & & 6.93 & & 18.2 & 7.6 & 27.6 & \\
\hline 3.36 & 7.56 & 19152 & 31.69 & 212 & 48 & 9.6 & & 2.04 & 6.07 & 7956 & 14.79 & 1.86 & 4 & 7.35 \\
\hline
\end{tabular}


Table 3. Characterization of the leachate treated with lime

\begin{tabular}{|c|c|c|c|c|c|c|c|c|c|c|c|c|c|c|}
\hline & & LP s & oernatant & rameters & & & MFT & & & & meate $\mathbf{P}$ & neters & & \\
\hline VFA & $\mathrm{pH}$ & COD & $\begin{array}{l}\text { Abs UV } \\
254\end{array}$ & Turbidity & MES & Conductivity & $F=0.2 \mathrm{~mm}$ & VFA & pH & COD & $\begin{array}{l}\text { UV Abs } \\
254\end{array}$ & Turbidity & MES & Conductivity \\
\hline $\mathrm{gCH}_{3} \mathrm{COOH} / \mathrm{L}$ & 12 & $\begin{array}{l}\mathrm{mgO}_{2} / \mathrm{L} \\
8743.00\end{array}$ & $\begin{array}{l}\text { DO } \\
6.69\end{array}$ & $\begin{array}{l}\text { NTU } \\
57.8\end{array}$ & $\begin{array}{l}\mathrm{mg} / \mathrm{L} \\
92\end{array}$ & $\mathrm{mS} / \mathrm{cm}$ & $\begin{array}{l}\mathrm{PTM}=1-2 \mathrm{bar} \\
\mathrm{Qr}=2 \mathrm{~m}^{3} / \mathrm{H}\end{array}$ & $\mathrm{gCH}_{3} \mathrm{COOH} / \mathrm{L}$ & 12 & $\begin{array}{l}\mathrm{mgO}_{2} / \mathrm{L} \\
7613\end{array}$ & $\begin{array}{l}\text { DO } \\
6.69 \\
\end{array}$ & $\begin{array}{l}\text { NTU } \\
12.2\end{array}$ & $\begin{array}{l}\mathrm{mg} / \mathrm{L} \\
36\end{array}$ & $\mathrm{mS} / \mathrm{cm}$ \\
\hline
\end{tabular}

Table 4. Characterization of the leachate treated with soda

\begin{tabular}{|c|c|c|c|c|c|c|c|c|c|c|c|c|c|c|}
\hline & & Raw & achate $\mathrm{p}$ & meters & & & MFT & & & Per & eate $P^{\prime} p$ & rameters & & \\
\hline VFA & pH & COD & $\begin{array}{l}\text { Abs UV } \\
254\end{array}$ & Turbidity & MES & Conductivity & $\mathrm{F}=0.2 \mathrm{~mm}$ & VFA & $\mathrm{pH}$ & COD & $\begin{array}{l}\text { UV Abs } \\
254\end{array}$ & Turbidity & MES & Conductivity \\
\hline $\begin{array}{l}\mathrm{gCH}_{3} \mathrm{COOH} / \mathrm{L} \\
4.8\end{array}$ & 7.57 & $\begin{array}{l}\mathrm{mgO}_{2} / \mathrm{L} \\
14489.20\end{array}$ & $\begin{array}{l}\text { DO } \\
31.1\end{array}$ & $\begin{array}{l}\text { NTU } \\
122\end{array}$ & $\begin{array}{l}\mathrm{mg} / \mathrm{L} \\
70\end{array}$ & $\begin{array}{l}\mathrm{mS} / \mathrm{cm} \\
8.34\end{array}$ & $\begin{array}{l}\mathrm{PTM}=1-2 \mathrm{bar} \\
\mathrm{Qr}=2 \mathrm{~m} 3 / \mathrm{H}\end{array}$ & $\begin{array}{l}\mathrm{gCH}_{3} \mathrm{COOH} / \mathrm{L} \\
4.2\end{array}$ & 13.4 & $\begin{array}{l}\mathrm{mgO}_{2} / \mathrm{L} \\
11374.2\end{array}$ & $\begin{array}{l}\text { DO } \\
17.1\end{array}$ & $\begin{array}{l}\text { NTU } \\
2.05\end{array}$ & $\begin{array}{l}\mathrm{mg} / \mathrm{L} \\
6\end{array}$ & $\begin{array}{l}\mathrm{mS} / \mathrm{cm} \\
14.55\end{array}$ \\
\hline
\end{tabular}


Table 5. Abatement of raw leachate

\begin{tabular}{lllll}
\hline & $\mathbf{E}_{\mathbf{1}}$ & $\mathbf{E}_{\mathbf{2}}$ & $\mathbf{E}_{\mathbf{3}}$ & $\mathbf{E}_{\mathbf{4}}$ \\
\hline & Yield \% & Yield \% & Yield \% & Yield \% \\
\hline COD & $31.57 \%$ & $19.14 \%$ & - & $58.46 \%$ \\
UV Abs 254 & $21.31 \%$ & $41.43 \%$ & $42.22 \%$ & $53.33 \%$ \\
Turbidity & $97.91 \%$ & $92.96 \%$ & $97.02 \%$ & $99.12 \%$ \\
MES & $90.00 \%$ & $92.00 \%$ & $92.72 \%$ & $91.67 \%$ \\
Conductivity & $3.83 \%$ & $-5.37 \%$ & - & $23.44 \%$ \\
VFA & - & - & - & $39.29 \%$ \\
\hline
\end{tabular}

Table 6. Reduction of leachate treated with lime and soda

\begin{tabular}{lll}
\hline & Leaching treated with lime & Reduction of leachate treated with soda \\
\hline Parameters & Yield \% & Yield \% \\
\hline COD & $12.92 \%$ & $21.50 \%$ \\
UV Abs 254 & $0.00 \%$ & $45.02 \%$ \\
Turbidity & $78.89 \%$ & $98.32 \%$ \\
MES & $60.87 \%$ & $91.43 \%$ \\
VFA & & 12.5 \\
\hline
\end{tabular}

Turbidity and suspended matter decreased when passing from the raw leachate and that filtered after lime treatment. The values obtained are lower than those obtained for the leachate which had not undergone any treatment. This result confirms that the lime treatment resulted in the reduction of organic and inorganic matter.

For leachate treated with soda, the values of the leachate treated are lower than those of the raw leachate and also lower than those of the leachate that has not undergone any treatment. Organic matter reduction rate in leachate.

The parameters measuring the reduction rate provide information on the loss of organic matter, its evolution during fermentation and its bioavailability after maturation of the compost. Thus, in Table 5, the results of the reduction rate of organic matter on the raw leachate are presented.

Analysis of the results shows that the abatement is optimal for turbidity and SS. On the other hand, the reduction in dissolved OM is low, as is that in salinity. The last yields are perhaps exaggeratedly good on soluble COD due to the clogging of the membranes which improves, if not the flow rates produced, at least the quality of the permeate.

From these results, it is essential that these leachate, which constitutes a source of contamination of the surrounding environments, be collected and treated before any discharge. The reduction rates of organic matter in the leachate treated with lime and soda is presented by Table 6 .

The analysis of the results of the characterization of the leachate shows, after treatment, a significant decrease in the various parameters determined. This significant difference thus indicates the effect of the treatment on the determined parameters.

Indeed, precipitation with lime in pretreatment is effective on the reduction of dissolved OM but not entirely, which is logical given the presence of AGV. Another advantage is also the speed of settling of the precipitate. The addition of lime at this $\mathrm{pH}<12-13\rangle$ has another advantage, apart from the cost, it is the possible stripping of the ammonia. The treatment with soda is not as effective as that with lime in pretreatment before microfiltration, which is logical insofar as the excess calcium allows better precipitation of carbonates.

After treatment of the raw leachate with lime and soda, these high COD values; absorbance at 254 $\mathrm{nm}$; turbidity and suspended matter have become very low, reflecting a high rate of abatement.

\section{CONCLUSION}

The characterization of the leachate resulting from the composting in fermentation of the composting platform of the city of Aného in Togo revealed a low chemical stability and consequently a high content of easily 
biodegradable organic matter, thus translating a significant mineral and organic load. The organic and mineral load is reflected in the high COD values; absorbance at $254 \mathrm{~nm}$; turbidity and suspended matter. The contents obtained in these pollutants remain higher than the accepted standards indicating the importance of the mineral and organic loads. However, after treatment of the raw leachate with lime and soda, these high COD values; absorbance at $254 \mathrm{~nm}$; turbidity and suspended matter have become very low, reflecting a high rate of abatement. From this study, monitoring analyzes and controlling the leachate is essential before any release into the surrounding environment.

\section{COMPETING INTERESTS}

Authors have declared that no competing interests exist.

\section{REFERENCES}

1. Hakkou. Marrakech public landfill: Characterization of leachate, study of their impact on water resources and testing of their treatment. University of CADI AYYAD, Morocco. 2001;150.

2. Hakkou R, Wahbi M, Bachnou A, Elamari K, Hibti M. Impact of the public landfill in Marrakech (Morocco) on water resources.» Bull Eng Geol. Approx. 2001;60:325336.

3. Fekri A, Wahbi M, Ben Bouzian A, Souabi $S$, Marrakchi M. State of the quality of groundwater downstream of the Mediouna landfill (Casablanca, Morocco). The First international symposium on the management of liquid and solid residus (MALISORE); 2004

4. Saadi S, Sbaa M, Kharmouz M. Physicochemical characterization of leachate from the technical landfill center in the city of Oujda (eastern Morocco). Science Lib., Editions Mersenne, 2013;5:112.

5. Mokhtaria MM, Eddine BB, Larbi D, Azzedine $\mathrm{H}$, Rabah L. Characteristics of the public landfill in the city of Tiaret and its impact on the quality of groundwater. Courrier du savoir. 2007;8:9399.

6. Bennama T, Younsi A, Zoubir D, Debab A. Characterization and physico-chemical treatment of leachate from the El-Kerma landfill (Algeria) by discontinuous adsorption on natural and chemically activated sawdust. Water Qual. Res J Can. 2010;45(1): 81-90.

7. Kouadio G, Dongui B, Trakourey A. Determination of the chemical pollution of the waters of the Akouedo landfill area (Abidjan-Cote d'Ivoire). Journal of Science and Technology. 2000;10(1):3341.

8. Kouame. Physico-chemical pollution of water in the Akouedo landfill area and analysis of the risk of contamination of the Abidjan water table by a simulation model of flows and pollutant transport. Doctoral thesis, University of Abobo Adjamé, Ivory Coast. 2007;212.

9. Segbeaya. Assessment of the impact of household waste in the city of Kara quality of the Kara river. Doctoral thesis from the University of Lomé in co-supervision with the University of Limoges. 2012; 226.

10. Toundou. Evaluation of the chemical and agronomic characteristics of five waste composts and study of their effects on the chemical properties of the soil, the physiology and the yield of maize (Zea mays L. Var. Ikenne) and tomato (Lycopersicum escul.» Doctoral thesis from the University of Lomé in co-supervision with the University of Limoges; 2016.

11. Kjeldsen P, Barlaz MA, Rooker AP, Baum A, Ledin A, Christensen TA. Present and long-term composition of MSW landfill leachate. Crit Rev About Sci Technol. 2002;32 (4):297-336.

12. Avnimelech $Y$, Bruner M, Ezrony J, Sela R, Kochba M. Stability indexes for Municipal Solid Compost. Compost Sci User. 1996;4(2):13-20.

13. Aguilar A, Casas C, Lema JM. Degradation of volatile fatty acids by differently enriched methanogenic cultures: Kinetics and Inhibition. Water Research. 1995;29:505509.

14. Lagier. Study of leachate macromolecules: Characterization and behavior with respect to metals. Thesis, University of Poitiers. 2000;189.

15. Kayey M, Mulungula P. Composting trial as a method of recycling solid household waste in the city of Bukavu in South Kivu (DR Congo). Déchets Sciences et Technique. 2013;30-38.

16. Toklo RM, Josse RG, Topanou N, Togbe AFC, Dossou-Yovo P, Coulomb B. Physico-chemical characterization of 
leachate from a landfill: Case of the Ouèssè-Ouidah sanitary landfill site

(southern Benin). International Journal of Innovation. 2015;13(4) : 921-928.

(c) 2021 Koledzi et al.; This is an Open Access article distributed under the terms of the Creative Commons Attribution License (http://creativecommons.org/licenses/by/4.0), which permits unrestricted use, distribution, and reproduction in any medium, provided the original work is properly cited.

Peer-review history:

The peer review history for this paper can be accessed here: http://www.sdiarticle4.com/review-history/66857 